\title{
Çikolata ve Sağlık Beyanları
}

\section{Chocolate and Health Claims}

\section{Tuğba Küçükkasap Cömert' ${ }^{1}$, Türkan Kutluay Merdol $^{2}$}

Geliş tarihi/Received: 19.12.2017 • Kabul tarihi/Accepted: 04.04.2018

\section{ÖZET}

Çikolata, bileşimindeki kakao oranı ve yapımında kullanılan maddelere göre bitter çikolata, sütlü çikolata vb. olarak adlandırılır. Kakao oranı ile en zengin olan bitter çikolatanın sağlık üzerine etkileri pek çok çalışmada değerlendirilmiş ancak tutarlı sonuçlar elde edilememiştir. Bazı araştırmalar, kakaonun yararlı etkisinin ancak çiğ tüketimi ile mümkün olabileceğini vurgularken, bazıları bitter çikolatanın yüksek doymuş yağ ve şeker içeriği nedeniyle vücut ağırlığında artışa neden olabileceğine dikkat çekmektedir. Bunun yanı sıra, kakao ve çikolata, teobromin ve kafein içeriğinden dolayı, belirgin yüksek nabız ile ilişkilendirilmekte, bu nedenle aritmisi olanlarda ve yaşlı hastalarda tüketiminin kısıtlanması gerektiği belirtilmektedir. Bununla birlikte, çikolatanın olumlu etkileri olduğunu gösteren bir çok çalışma da bulunmaktadır. $\mathrm{Bu}$ çalışmalarda, çikolatada bulunan sağlıksız bileşenlere karşllık, olumlu etkilerinin değerlendirilmesi gerektiği vurgulanmakta, istenmeyen olumsuz etkileri engellemek için uygun miktarlarda tüketilmesi gerektiği belirtilmektedir. Bu derlemede, çikolata ve sağlık beyanları üzerine yapılan çalışmalar ve sonuçları değerlendirilmiştir.

Anahtar kelimeler: Çikolata, besin içeriği, sağllk

\begin{abstract}
Chocolate is classified as bitter chocolate, milk chocolate etc. according to the proportion of dry cocoa and other ingredients in its composition. The health effects of bitter chocolate, which has the highest cocoa ratio, were evaluated in many studies, but the results were very conflicting. Some investigations emphasize the beneficial effect of cocoa could only be possible with raw consumption. Some notes that bitter chocolate may cause an increase in body weight due to the high saturated fat and sugar content. In addition, cocoa and chocolate are being associated with a significantly increased pulse rate because of their theobromine and caffeine content, suggesting the consumption should be restricted in patients with arrhythmia and elderly. However, there are many studies showing the positive effects of chocolate. These studies are stating that the positive effects should not be ignored regardless the unhealthy components in cocoa and chocolate and emphasize the necessity of consumption of the chocolate in reasonable quantities to prevent unwanted adverse effects and get the beneficial ones. In this review, findings of the investigations on the relation of chocolate and health were evaluated.
\end{abstract}

Keywords: Chocolate, nutrients content, health

1. İletişim/Correspondence: Yüksek İhtisas Üniversitesi, Beslenme ve Diyetetik Bölümü, Ankara, Türkiye • E-posta: tugbacomert@yiu.edu.tr ○ https://orcid.org/0000-0001-8925-2586
2. Atılım Üniversitesi, Beslenme ve Diyetetik Bölümü, Ankara, Türkiye 은tps://orcid.org/0000-0002-0783-947X 


\section{GíRiş}

Çikolata, sıkça tüketilen lezzetli bir yiyecek olmasının yanı sıra, sağlık üzerine olası olumlu ve olumsuz etkileri nedeniyle birçok araştırma için hedef besin olmuştur (1). Onaltıncı yüzyıldan günümüze kadar, kakao ve çikolatanın anemi, ateş, tüberküloz, ince bağırsak hastalıkları, böbrek taşları, bazı tümörlerin tedavisi de dahil olmak üzere pek çok hastalık ve sendromda etkisi olduğu ifade edilmiştir. Özellikle, kakaonun kalp ağrıları üzerine olumlu etkileri olduğu, kalbi güçlendirdiği, karaciğere iyi geldiği, sindirime yardımcı olduğu ve uykuyu kolaylaştırdığına dair inanışlar mevcuttur (2). Günümüzde, kakao ve çikolatının, tip 2 diyabet (DM) ve kardiovasküler hastalıklar $(\mathrm{KVH})$ ile ilintili risk etmenleri, kan lipit profili, antioksidan kapasite, insülin direnci, kan basıncl, inflamasyon ve obezite üzerine etkilerine dair bilimsel çalışmalar yaygınlık kazanmıştır $(1,3,4)$. $\mathrm{Bu}$ derleme yazıda çikolata, içerdiği enerji, besin ögeleri, biyoaktif ögeler ve bunların sağlık üzerine olası etkileri değerlendirilmiştir.

\section{Çikolata Tarihçesi, Tanımı, Besin Değeri, Üretim Aşamaları}

Arkeolojik bulgulara göre kakao ilk kez M.Ö. 400’lü yıllarda Orta Amerika'da imparatorluk kuran Mayalar tarafından içecek olarak tüketilmeye başlanmıştır. Aztek kültüründe de kutsal olarak kabul edildiğine dair de pek çok bulgunun bulunduğu, 14. yy.'dan Amerika'nın keşfine kadar Orta Amerika'da yaygın olarak tüketildiği belirtilmektedir. Deniz yolu ile farklı ülkeleri keşif seyahati sırasında Kristof Kolomb’un çikolata içeceğini tüm dünyaya tanıttığı ve 1502'de Nikaragua'ya kadar ulaştırdığı ifade edilmektedir. Aztekler tarafından kakao tohumları uyarıcı etkisi nedeni ile, "xocolatl" olarak isimlendirilmiş ve içecek şeklinde tüketilmiş, xocolatl ismi daha sonra tüm dünyada kakao ürünleri için kullanılmaya başlanmıştır. İspanyolların 16. yy.'da kakao içeceğini tüketen ilk Avrupalılar olduğu belirtilmektedir (5).

Günümüzde, yaklaşık 40-50 milyon bireyin kakao tarımından gelir elde ettiği belirtilerek, üretimin dünyada 4.2 milyon tona ulaştığı ve bunun 11.8 milyar dolar gelire eşdeğer olduğu, geçtiğimiz on yılda büyüme hızının yılda \%3’e çıktığının altı çizilmektedir. Dünya kakao üretiminin \%33’lük en büyük payının Afrika Fildişi sahilinden sağlandığı, bunu Ghana’nın izlediği belirtilmektedir (Tablo 1) (5).

Tablo 1. Dünyada ylllık kakao üretimi (Dünya Kakao Birliği, 2014-2015)

\begin{tabular}{llc}
\hline Kıta & Ülke & Üretim payı (\%) \\
\hline \multirow{2}{*}{ Afrika } & Fildişi Sahili, Ghana, Nijerya, & 68 \\
& Kameron & \\
Asya & Papua Yeni Gine, Malezya, & 17 \\
Amerika & Kndonezya & 15 \\
\hline
\end{tabular}

Kakao ağacı, yaklaşık olarak ekvatorun 20 derece kuzey ve güneyinde yetişen dayanıklı bir ağaç olarak tanımlanmaktadır. Rakım olarak deniz seviyesinden 400 metre yükseklikte, $18-35^{\circ} \mathrm{C}$ sıcaklıkta yetiştirildiği bildirilmektedir. Kakao tohumundan, kakao likörü (kakao meyvelerinin kavrulup ögütülmesi ile elde edilen yarı akışkan yağlı ürün), kakao tozu (kakao tohumlarının kavrulması ve preslenmesi aşamalarındansonraeldeedilmektedir,yaklaşıkolarak \%10 yağ içeriğine sahip olduğu, selüloz, hemiselüloz ve lignin gibi polisakkaritler içerdiği saptanmıştır) ve kakao yağı elde edilmekte ve bu ürünler kakao içeceği, çikolata yapımı, dondurma yapımı ve pek çok pastacılık ürünlerinde kullanılmaktadır (5).

Çikolata, kakao likörünün, kakao yağı, şeker ve süt gibi besinlerle karıştırılarak yapılması ile edilen yiyecek olarak tanımlanabilir. Çikolata içerdiği bu besinlerin tür ve miktarına göre bitter çikolata, sütlü çikolata, beyaz çikolata gibi adlarla anılır. Çikolatanın elde edilmesi, karıştırma, inceltme, konçlama, temperleme ve paketleme olmak üzere beş temel basamaktan geçen uzun bir süreç olarak belirtilmektedir. Çikolatanın kalitesini belirleyen unsur kakao yağı oranı olarak gösterilmekte, kakao yağı oranı arttıkça çikolatanın kalitesinin arttığı ifade edilmektedir. Çikolata eritilirken doğrudan ateşte değil, benmari usulü eritilmesi gerektiğine, doğrudan 
ateşte eritilirse, çikolatada yanma denilen olayın meydana geleceğine dikkat çekilmektedir (4).

Çalışmalara sıklıkla konu olan bitter çikolata, kakao likörü ve kakao yağından oluşmaktadır. Amerikan Gıda ve İlaç Dairesi'nin 2016 raporuna göre, bitter çikolatadaki kakao likörü miktarı ağırlığının \%35'inden az olmaması gerekmektedir. Kakao tohumlarının \%50-57'si yağdır. Kakao tohumları kavrulduktan sonra toz haline getirilmeden önce bu yağ ayrılır. Sütlü çikolatadaki kakao likörü miktarı, bitter çikolataya göre daha az olmakla birlikte, sütlü çikolatanın bileşiminde kakao yağına ek olarak süt yağı da bulunmaktadır (4).

Kakao likörü, vitamin, mineral, posa ve polifenoller açısından zengin bir içeriğe sahiptir. Çikolataya yumuşaklığını ve lezzetini veren kakao yağı ise vitamin, mineral ve polifenoller içermez. Kakao yağının bileşimini, \%33 stearik asit, \%33 oleik asit ve \%25 palmitik asit oluşturur (4).

Genel olarak bitter çikolatadaki toplam kakao miktarı \%50-85 arasında iken sütlü çikolatada bu değer \%20 -30 arasındadır. Tablo 2'de düşük yağlı ve yüksek yağlı kakaonun, şeker ilavesiz çikolata, bitter çikolata ve pastacılıkta kullanılan çikolatanın besin içeriği özetlenmiştir (4).

Kakao tohumlarının kuru ağırlığının yaklaşık \%6-8'ini polifenoller oluşturmaktadır. Epikateşin, kateşin ve prosiyanidin gibi flavanollerin yanı sira antosiyanin, fenolik asit ve stilbenler, kakao tohumundaki temel polifenollerdir (6). Bitter çikolatanın 10 gramındaki toplam polifenol miktarı yaklaşık 120-150 mg kadar iken, kakao tozunda bu miktar 5 katına kadar çlkabilmektedir. Sütlü çikolatanın polifenol içeriği ise toplam kakao miktarının azalmasına bağlı olarak daha düşüktür (7). Bitter çikolatadaki kateşin içeriği $12 \mathrm{mg} / 100 \mathrm{~g}$, epikateşin içeriği ise $41.4 \mathrm{mg} / 100 \mathrm{~g}$ olarak bulunmuştur (8). Bu miktar çaydan yaklaşık 20 kat, sütlü çikolatadan ise yaklaşık 4 kat daha fazladır (6). Kateşinler vücutta, plazma antioksidan aktivite, bronşial arter dilatasyonu, yağ oksidasyonu ve düşük dansiteli lipoprotein (LDL) oksidasyonuna dirençte görev alır. $\mathrm{Bu}$ anlamda bitter çikolatanın sağlık üzerine olumlu etkilerinin çoğu, zengin kateşin içeriği ile ilişkilendirilmektedir (8).

Bitter çikolatanın antioksidan kapasitesinin değerlendirildiği bir çalışmada Bitter çikolatanın serbest radikalleri emme kapasitesi (ORAC) $13.1 \mu \mathrm{mol}$ troloks eşdeğeri (TE)/100g olarak bulunmuştur (8). Ancak antioksidan aktivitenin kakao tohumlarının yetiştiği bölgeye ve hasat özelliklerine göre değişebildiği belirtilmektedir. Kakao çekirdeğinin işleme yönteminin son polifenol içeriğini belirleyen en önemli etmen olduğu işleme düzeyine bağlı olarak aynı kakao içeriğine sahip iki çikolatanın flavonol içeriğinin farklı olabileceği gösterilmiştir (9). Ayrıca üretim aşamasında yüksek sıcaklık ve pH'nın özellikle epikateşin ve kateşin olmak üzere belirgin flavonol kayıplarına neden olabileceği saptanmıştır (10). Bunun yanı sira kakaonun belirgin bir genetik çeşitliliğe sahip olduğu ve 1400'ün üzerinde kakao çeşidinin var olduğu belirtilmiştir. $\mathrm{Bu}$ nedenlerle çikolatanın antioksidan kapasitesine ilişkin net bir sayı verilmesi doğru değildir (11).

Övet (12), Türkiye'de piyasada satılan çikolataların ortalama antioksidan kapasiteleri ve fenolik madde

Tablo 2. Düşük yağlı ve yüksek yağlı kakaonun, şeker ilavesiz çikolata, bitter çikolata ve pastacılıkta kullanılan çikolatanın besin içeriği (\%)

\begin{tabular}{lccccc}
\hline $\begin{array}{l}\text { Enerji ve besin } \\
\text { ögeleri }\end{array}$ & $\begin{array}{c}\text { Kakao } \\
\text { düşük yağlı }\end{array}$ & $\begin{array}{c}\text { Kakao } \\
\text { yüksek yağlı }\end{array}$ & $\begin{array}{c}\text { Şeker ilavesiz } \\
\text { çikolata }\end{array}$ & Bitter çikolata & $\begin{array}{c}\text { Pastacılık ürünlerinde } \\
\text { kullanılan çikolata }\end{array}$ \\
\hline Karbonhidrat & $45-60$ & $45-60$ & $30-35$ & $20-50$ & $50-70$ \\
Protein & $17-22$ & $15-20$ & $10-15$ & $5-10$ & $3-8$ \\
Yağ & $10-15$ & $20-25$ & $45-55$ & $33-45$ & $20-35$ \\
Posa & $20-35$ & $30-35$ & $15-20$ & $5-8$ & $3-8$ \\
Enerji (kkal) & 200 & 300 & $470-500$ & $500-550$ & $450-550$ \\
\hline
\end{tabular}


içeriklerini ölçmüş ve bitter çikolata örneklerinin antioksidan kapasitenin $(2.652 \pm 0.093 \mathrm{mg} / \mathrm{mL})$, toplam fenolik (568.81 $\pm 48.54 \mathrm{mg} / 100 \mathrm{~g}$ ), toplam epikateşin (EC) miktarlarının $(0.192 \pm 0.081 \mathrm{mg}$ (EC/g), sütlü çikolataya göre (sırası ile $0.473 \pm 0.07 \mathrm{mg} / \mathrm{mL}, 168.67 \pm 9.22 \mathrm{mg} / 100$ g, $0.069 \pm 0.0050 \mathrm{mg} \mathrm{EC/g)} \mathrm{önemli} \mathrm{ölçüde} \mathrm{daha} \mathrm{yüksek}$ olduğunu saptamıştır (12).

\section{Çikolatanın Hastalıklarla İlişkisi}

\section{Kardiyovasküler hastalıklar}

Yapılan birçok epidemiyolojik çalışmada, düzenli çikolata tüketimi ve $\mathrm{KVH}$ arasında negatif ilişki gösterilmiştir (13-15). Kesitsel çalı̧malardan oluşan meta analiz çalışmaları ile kohort çalışmalarından oluşan meta analiz çalışmalarında, yüksek miktarda çikolata tüketiminin düşük KVH (\%37) ve inme (\%29) riski ile ilişkili olduğu sonucuna varılmıştır (16).

Kakao polifenollerinin KVH'daki rolü üzerine bir görüş birliği bulunmamakla birlikte, olası mekanizmanin, antiinflamatuvar, antioksidan, antiplatelet agregrasyonu ve vazodilatif özellikleri ile ilişkili olabileceği belirtilmektedir (17). Kakao polifenollerinin, lökotrienleri azaltıp prostasiklinleri (vazodilatör) arttırarak, eikozanoid (vazokonstriktör) aktivitesini düzenlediği saptanmıştır (18). Ayrıca 2-4 haftalık insan çalışmalarında, kakao ve bitter çikolatanın, endotelyal disfonksiyon göstergesi olan akım bağımlı dilatasyonu (FMD) (19), askorbik asidi (20), tiyobarbitürik asit reaktiflerini (TBARs) (21), oksijen radikal emilim kapasitesini (ORAC) ve F2isoprostanları (22) arttırmada, branşial damarların vasküler daralmasını azaltmada (23) etkin olduğu saptanmıştır.

Polifenollerin olumlu etkilerinin yanı sıra kakaoda bulunan bitkisel steroller ve posa da, kan yağlarını düşürücü etki göstererek, kardiovasküler sağllğın korunmasında önemli rol oynayabilmektedir. Ayrıca kakaonun yapısında bulunan potasyum, kalsiyum, magnezyum ve bakır gibi mineraller de kardiyovasküler sağllğın geliştirilmesinde yardımcidır (6).
Olası olumlu etkilere rağmen 21 yetişkin bireyin iki hafta boyunca değerlendirildiği randomize kontrollü klinik çalışmada yüksek (259 mg flavanoid) ve düşük flavanoid içeriğine sahip bitter çikolata tüketiminin LDL oksidasyonunda belirgin bir değişikliğe neden olmadığı gözlemlenmiştir (24).

\section{Kan yağları}

Kakao ve çikolatanın kan yağları üzerine etkisinin değerlendirildiği çalışmalar incelendiğinde, kısa dönemli çalışmaların (2 hafta), uzun dönemli çalışmalara göre kan yağlarını azaltmada daha etkin olduğu görülmektedir $(19,22,23,25)$. Bu durum uzun dönemli çalışmalarda uyumun azalması ile ilişkilendirilmektedir. Yine çalışmalarda çoğunlukla, LDL ve total kolesterol (TK) düzeylerindeki azalmanın kardiyovasküler riske sahip bireylerde belirgin olduğu, sağlıklı bireyler üzerinde herhangi bir etkinin olmadığı göze çarpmaktadır. Ayrıca kan yağları üzerine yararlı etkinlik için polifenollerin optimal dozu konusunda henüz bir veri de bulunmamaktadır $(19,22,23,25)$.

Genel olarak bitter çikolatanın lipit profili üzerine olası olumlu etkileri zengin polifenol içeriği ve oleik asit içeriğiyle ilişkilendirilmektedir. Jie ve arkadaşlarının (25) 8 çalışmayı değerlendirdiği bir meta analizde, kakao/bitter çikolata tüketiminin LDL düzeylerinde belirgin azalma $(-5.87 \mathrm{mg} / \mathrm{dL})$, TK düzeylerinde ise istatistiksel açıdan anlamlı olmayan bir azalma $(-5.82 \mathrm{mg} / \mathrm{dL})$ sağladığı belirtilmiştir. On çalışmanın değerlendirildiği başka bir meta analiz çalışmasında ise, kakaonun serum TK ve LDL düzeylerinde bir azalma $(-6.23 \mathrm{mg} / \mathrm{dL},-5.9 \mathrm{mg} / \mathrm{dL})$ sağladığı, ancak yüksek dansiteli liporprotein (HDL) ve trigliserit (TG) düzeylerinde belirgin bir etki göstermediği saptanmıştır (13).

\section{İnflamasyon}

Kakao ve çikolatanın inflamasyon üzerine etkisini inceleyen çalışmalarda da benzer şekilde tutarlı sonuçlar elde edilememiştir. Beş çalışmanın değerlendirildiği bir meta analizde, flavonoidden 
zengin çikolata tüketiminin C-reaktif protein (CRP) düzeyleri üzerine belirgin bir etkisinin olmadığı belirtilmiştir (26). Bulgular, on çalışmanın değerlendirildiği, kakao/bitter çikolatanın CRP düzeyleri üzerine etkin olmadığ sonucuna varılan meta analiz çalışması (27) ile tutarlılık göstermektedir. Buna karşılık Hamed ve arkadaşları (28) bir hafta boyunca $700 \mathrm{mg} / \mathrm{gün}$ flavonoid içeriğine sahip bitter çikolata tüketen kadın bireylerde yüksek duyarlı C-reaktif protein (hs-CRP) düzeylerinde azalma (1.8 $\pm 2.1 \mathrm{mg} / \mathrm{L}$ 'den $1.4 \pm 1.7 \mathrm{mg} / \mathrm{L’ye})$ saptamışlardır.

İnflamasyon üzerine elde edilen çelişkili bulgular, polifenol miktarları arasındaki farka ve yarılanma ömürleri ile ilişkilendirilmekte olup, olumlu verilerin kısa dönemli çalışmalarda elde edildiği belirtilmektedir (29,30). Ayrıca çalışmalarda, inflamasyonu arttırıcı bir etken olduğu kanıtlanan diyet doymuş yağ içeriğinin göz ardı edildiğine dikkat çekilmektedir (1).

\section{Diabetes mellitus}

Laboratuvar çalışmalarından elde verilere göre çikolata ve kakao polifenollerinin insülin direnci ve DM üzerine olası etkileri, glukoz emilimini azaltarak ve insülinin hedef hücrelerde kullanımını arttırarak ve dokularda glukoz kullanımını regüle ederek gerçekleşmektedir (Şekil 1) (30).

İnsanlar üzerinde yapllan randomize kontrollü çalışmalarının sonuçları ise çoğunlukla olumludur. Shrime ve arkadaşlarının (26) yaptığı beş çalışmanın değerlendirildiği bir meta analizde, sağllklı bireylerde kakao/bitter çikolatanın homa insülin direnci testi (HOMA-IR) değerinde belirgin azalma sağlarken, glukoz düzeyleri ve kantitatif insülin duyarlılığı kontrol indeksinde (QUICKI) belirgin bir etki sağlamadığı belirtilmiştir (26). Altı çalışmanın değerlendirildiği bir başka meta analizde ise, sağlıklı bireylerde kakao/bitter çikolata tüketiminin HOMAIR'de belirgin azalma $(-0.67 \mu \mathrm{IU} / \mathrm{mL})$, ancak kan glukoz veya QUICKI de herhangi bir etki göstermediği, kakao/bitter çikolatanın olası etkisini insulin salınımı azaltarak oluşturduğu belirtilmiştir (31).

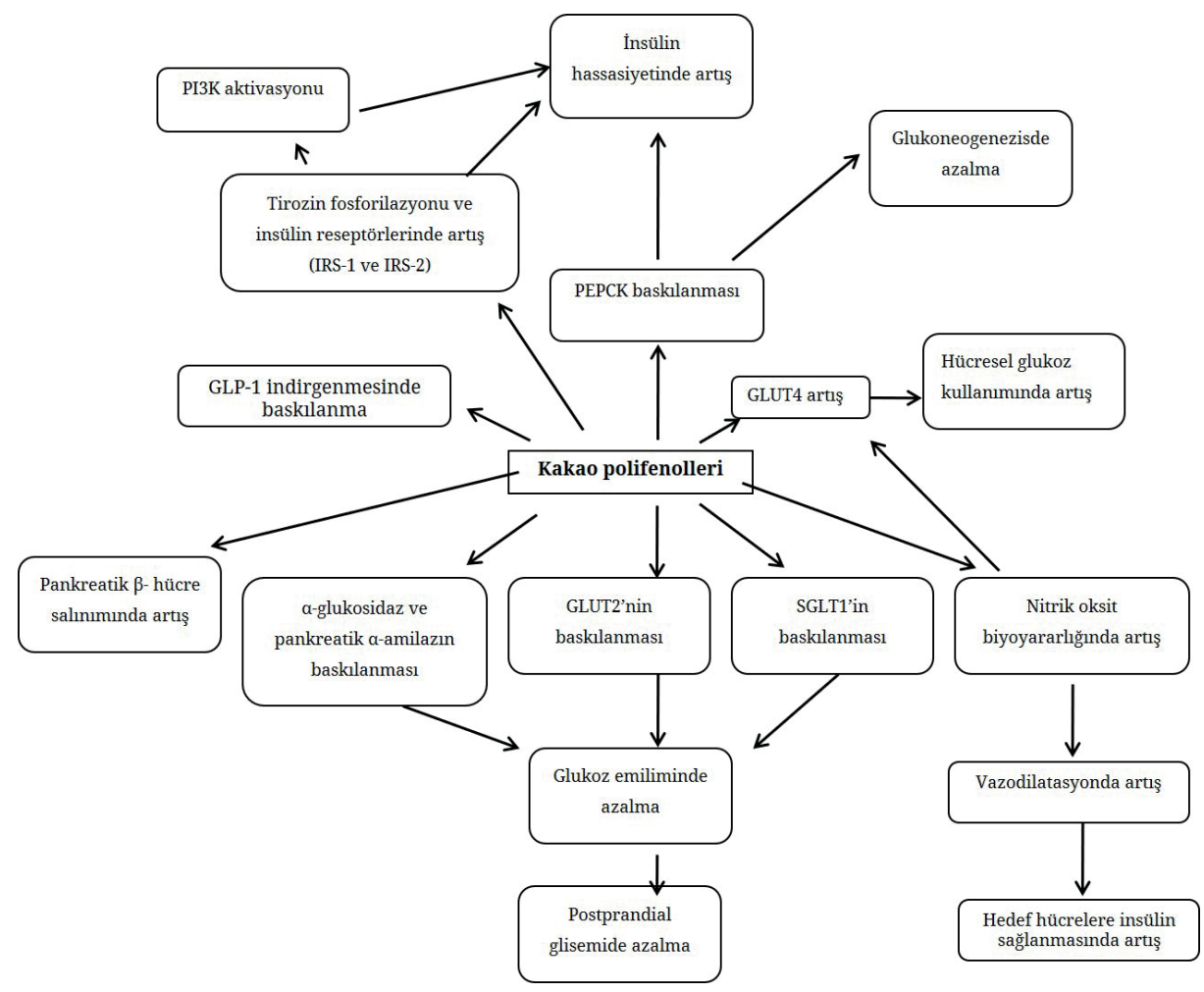

Şekil 1. Kakao polifenollerinin insülin ve glukoz metabolizması üzerine olumlu etkileri (30) 
Atherosclerosis Risk in Communities Cohort çalışmasında 13 yıllık izlem sonucunda, çikolata tüketim sıklığı ve diyabet gelişim riski arasında negatif ilişki gösterilmiştir (32). Oba ve arkadaşlarının (33) çalışmasında benzer şekilde, 10 ylllık izlem süreci sonunda 13.000 Japon bireyde atıştırmalık olarak çikolata tüketimi ile (ayda bir kezin altında 28 g çikolata tüketen bireylerde, ayda en az bir kez $28 \mathrm{~g}$ çikolata tüketenlere göre) DM gelişim riski arasında negatif ilişki saptamışlardır. Risk düzeyindeki en çarpıcı azalma \%34 ile, haftada 2-6 kez çikolata tüketenlerde belirlenmiştir. Buna karşılık günde en az bir kez çikolata tüketenlerde DM gelişim riskinde azalma saptanmamıştır (33).

Genel olarak değerlendirildiğinde, ılımlı miktarda çikolata tüketimi ile sağlanan flavanoidlerin, çikolatanın yüksek yağ ve şeker içeriğine rağmen koruyucu etki gösterebildiği sonucuna varılmıştır (33).

\section{Kan basıncı}

Kakao/bitter çikolatanın kan basıncı üzerine olası etkileri ilk kez Panama'daki Hintliler üzerinde yapılan çalışmalarda ortaya konulmuştur. Günde üç kez $30 \mathrm{~g}$ kakao tüketiminin (toplamda $900 \mathrm{mg}$ flavanol), yüksek sodyum alımlarına karşılık kan basıncını düşürdüğü (110/70 mmHg) gösterilmiştir (34).

Kakao/bitter çikolatanın kan basıncı üzerine olası etkisi artan nitrik oksit (NO) ve vazodilatör etkisi ile açıklanmaktadır (35). Ayrıca kakao flavanollerinin NO'den bağımsız olarak, prostasiklin ve endotelyum kaynaklı hiperpolarizasyon ile de vazodilatasyonu arttırabileceği düşünülmektedir (36) .

Yetmiş çalışmanın değerlendirildiği bir meta analizde, kan basıncının düşürülmesinden sorumlu temel flavanoidin epikateşin olduğu vurgulanmıştır. Epikateşin içeriği $25 \mathrm{mg}$ olan kakao veya çikolata tüketiminin, sistolik kan basıncını 4.1 mmHg, diastolik kan basıncını $2 \mathrm{mmHg}$ düzeyinde düşürdüğü belirtilmiştir (37). Buna karşılık Hooper ve arkadaşlarının (31) yaptığı meta analizde ancak 50 mg/gün üzerindeki epikateşinin kan basıncı üzerine belirgin etki sağlayabileceği bildirilmiştir.

Hipertansif bireylerin aksine normotansif bireylerde ise kakao/bitter çikolatanın kan basıncını düşürücü etkisi gösterilememiştir. Murphy ve arkadaşları (34), 234 normotansif birey üzerinde yaptığı çalışmada toplamda $234 \mathrm{mg}$ flavanol ve prosiyanidin alımının kan basıncı üzerine herhangi bir etkisi olmadığı sonucuna varılmıştır. Benzer bulgular Engler ve arkadaşları (24) (259 mg flavanoid), Crews ve arkadaşları (754.71 mg proantosiyanidin) (38,39), Njike ve arkadaşları (805 mg flavanol) (40) ve Di Renzo ve arkadaşları (2000 mg polifenol) (41) tarafindan da elde edilmiştir.

\section{Vücut ağırlığı ve obezite}

Genel olarak yüksek enerji içeriğine sahip çikolata, dengeli bir beslenme örüntüsü ile tüketilmediğinde vücut ağırlığında artış ile sonuçlanmaktadır (1). Ancak kakao/bitter çikolatanın vücut ağırlığının denetimi üzerine olumlu etkileri olabileceği değerlendirilmekte (Şekil 2) ve bu kapsamda yapılan çalışmalardan da olumlu sonuçlar elde edilmektedir (3).

Bitter çikolatanın NO kullanımını arttırarak adipoz dokuda lipolizi uyardığı, yă̆ asidi sentezini baskıladığı, glukoz ve yağ asidi oksidasyonunu arttırdığı gösterilmiştir (42). Yapılan bir hücre çalışmasında, farklı dozlardaki kakao ekstraktının sindirim enzimleri pankreatik a-amilaz, pankreatik lipaz, pankreatik fosfolipaz A2 üzerine etkisi incelenmiş, kakao ekstraktının bu enzimlerin aktivitesini baskılayarak karbonhidrat ve yağ sindirimini azaltabileceği gösterilmiştir. Bu bulgular kakaonun, orlistat gibi sindirim enzimlerini hedef alan bir ajan olabileceğini ve makro besin ögelerinin emilimini azaltarak obeziteyle mücadelede yardımcı rol oynayabileceği fikrini desteklemektedir $(43,44)$.

İnsanlar üzerinde yapılan bir RCT çalışmasında ise zıt sonuçlar elde edilmiş, 2-8 haftalık süreç boyunca 2592135 mg polifenol içeriğine sahip 20-50 g/gün çikolata tüketiminin vücut ağırlığı üzerine herhangi bir etkisi olmadığı sonucuna varılmıştır $(23,40,42)$. 


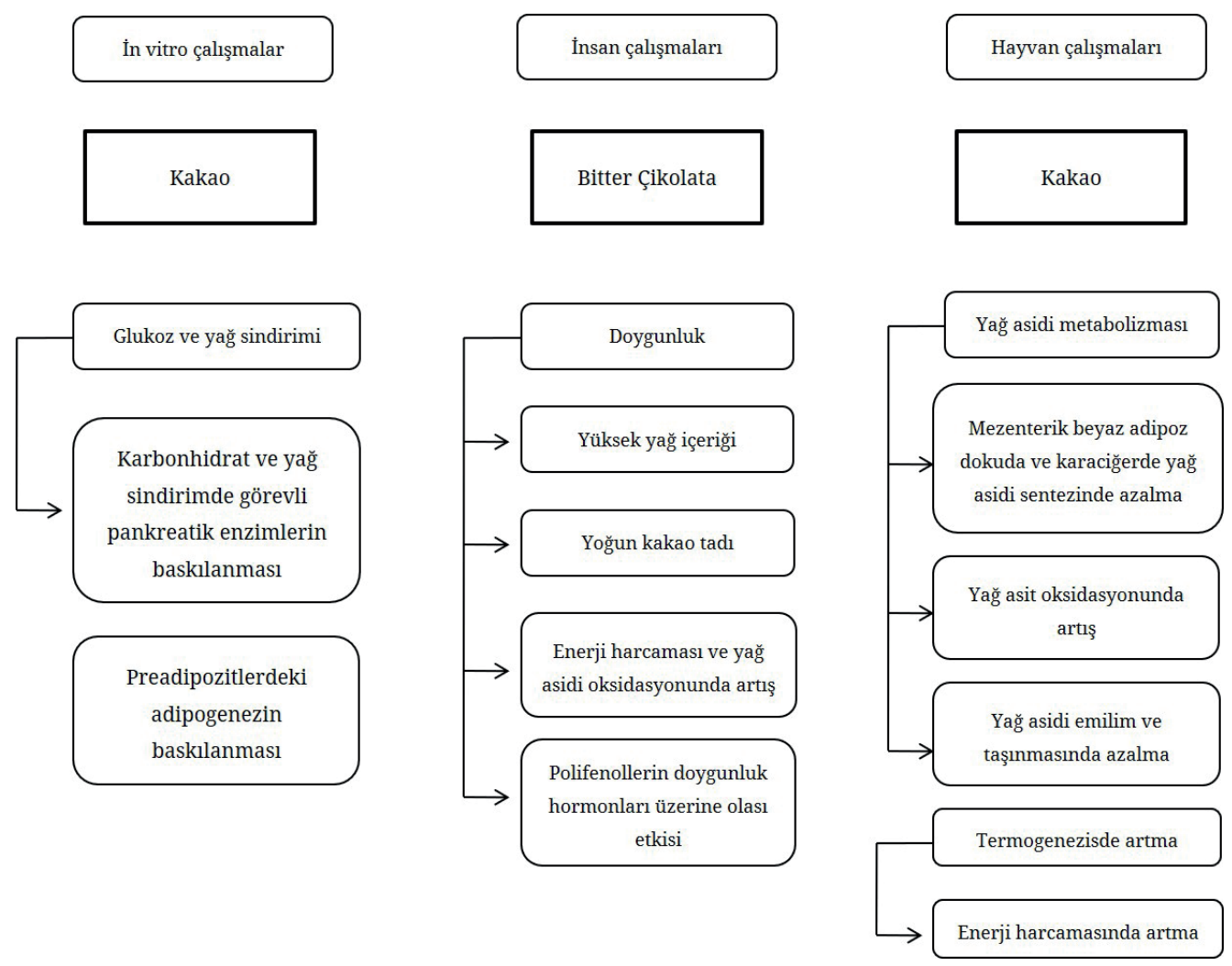

Şekil 2. Kakao ve bitter çikolatanın vücut ağırlığı denetimi üzerine olası etkisi (3)

\section{Ruhsal durum}

Çikolatanın ruhsal durum üzerine etkisinin değerlendirildiği çalışmalarda, çikolata yapısındaki $\mathrm{N}$-asetil etanolaminin, kannabinoid reseptörleri aktive ederek endokannabinoid düzeylerini arttırabileceği, böylelikle haz ve duygu durumunun düzenlenmesinde rol oynayabileceği gösterilmiştir (45). Ancak çikolatanın ruhsal durum üzerine oluşturduğu olumlu etkiler, sadece içerdiği psikoaktif bileşenlerle ilişkili değil, tat, yapısal özellikler, karbonhidrat ve yağ oranı gibi tüm özelliklerin oluşturduğu ortak bir sonuçtur (46).

Martin ve arkadaşları (47) yaptığı çalışmada, bireyler çalışma başında Durum-Sürekli Kaygı Envanterine göre düşük veya yüksek kaygı düzeyine sahip olarak sınıflandırılmıştır. Çalışma süreci boyunca bireylerin $40 \mathrm{~g} /$ gün bitter çikolata tüketimi sağlanarak 3. 7. ve 14. günde idrar örnekleri toplanmıştır. Yüksek kaygı düzeyinesahipbireylerin,enerjihomeostazında(laktat, sitrat, süksinat, trans-akonitat, üre, prolin), hormonal metabolizmalarında (adrenalin, DOPA, 3-metoksi tiramin ve bağırsak mikrobiyal aktivitelerinde (metilaminler, p-krezol sülfat, hippürat) belirgin farklılıklar gözlemlenmiştir. Bitter çikolata tüketiminin, idrarla katekolamin ve stres hormonu kortizol atımını azalttığı, enerji metabolizması (glisin, sitrat, trans-akoniat, prolin, $\beta$-alanin) ve bağırsak mikrobiyal aktivitesini (hippurate, p-kreaol sülfat) normalize ettiği belirlenmiştir. Bitter çikolatanın olası etkilerini bağırsak mikrobiyotasını düzenleyerek gösterdiği, hormonal ve metabolik etkilerin mikrobiyal aktivitenin regülasyonuyla ile ilişkili olabileceği düşünülmektedir (47).

Çift kör plasebo kontrollü başka bir çalışmada, kakao tozu ve metilksantin bulunan $50 \mathrm{~g}$ bitter çikolatanın bilişsel işlev ve ruhsal durum üzerine etkisi değerlendirilmiştir. Bireyler benzer miktarlarda hiç metilksantin içermeyen beyaz çikolata, düşük miktarda (8 mg kafein $+100 \mathrm{mg}$ teobromin) ve yüksek miktarda (20 mg kafein $+250 \mathrm{mg}$ teobromin) metilksantin içeren çikolata tüketmişlerdir. Çalışmanın sonunda, çikolatanın psiko-uyarıcı etkisinin temel olarak içerdiği metilksantinler ile ilişkili olduğu sonucuna varılmıştır (46). 
Başka bir çalışmada ise 258 bireyde 75 kkal enerji içeriğine sahip eşdeğer miktarda bilinçli veya bilinçsiz çikolata ve kraker tüketiminin ruhsal durum üzerine etkisi değerlendirilmiştir. Bilinçli tüketim, daha yavaş tüketim süresi, daha çok çiğneme, tat, koku, lezzet öğelerine daha çok dikkat ile karakterize edilmiştir. Bilinçli bir şekilde çikolata tüketiminin, bilinçsiz çikolata tüketimi ve bilinçli/bilinçsiz kraker tüketimine göre ruhsal durum üzerine olumlu etki sağladığı bulunmuştur (48).

\section{Afrodizyak etki}

Çikolatada belirtilen afrodizyak özellik, sıklıkla tükettikten sonra ortaya çıkan duyusal memnuniyet ile ilişkilendirilmektedir. Bunun yanı sıra, çikolatanın tatlı ve yağlı doğal yapısının hipotalamusu uyardığı, haz duygusu oluşturduğu, beyindeki serotonin düzeylerini etkileyerek afrodizyak etkinin ortaya çıkmasını sağladığı belirtilmektedir. Ayrıca, çikolatanın insanda kannabinoid reseptörlerini aktive edebildiği veya endokannobinoid düzeylerini arttırabilen doymamış $\mathrm{N}$-asetiletanolaminler içerdiği ve böylece kendini aşırı derecede iyi hissetme hali oluşturabildiği belirtilmektedir (45).

Kakaonun, sempatomimetik biyojenik aminler (tiramin ve feniletilamin) ve metilksantin (teobromin, kafein) gibi birçok potansiyel psikoaktif bileşene sahip olduğu bildirilmektedir. Çikolatada 660 $\mathrm{mg} / 100 \mathrm{~g}$ feniletilamin bulunduğu ve bunun insan vücudunda dopamin ve noradrenaline benzer uyarıcı etki oluşturduğu belirtilmiştir. Feniletilaminin, kan basıncını ve kalp atım hızını arttırdı̆̆ı, duyguları güçlendirici etki yaratabildiği gözlemlenmiştir. Yine çikolata tüketimin oluşturduğu anlık enerji yüklemesinin dayanıklılığı arttırabileceği öne sürülmüştür. Ancak bu etkilerin tamamı çikolatayı afrodizyak olarak nitelendirmek için yetersiz kalmaktadır (45).

\section{Bilişsel işlev}

Çikolatanın bilişsel işlev üzerine etkinliği üzerine yapılan çalışmaların, kafein içeriği ile ilişkili olduğu belirtilmektedir $(48,49)$. Yapılan çalışmalarda
$520 \mathrm{mg}, 720 \mathrm{mg}$ ve $994 \mathrm{mg}$ kafein içeriğine sahip çikolataların bilişsel işlev üzerinde etkin olduğu, gelişen bilişsel etkinin 90 dakikada ortaya çıktığı ve 2 saat civarında en üst düzeye ulaştığı belirlenmiştir. Ancak gelişen bilişsel işlevin oluşması için tüketilmesi gereken en az kafein miktarı $120 \mathrm{mg}$ ve $700 \mathrm{mg}$ theobromine olarak belirtilmekte, bu da çikolatanın içeriği değerlendirildiğinde oldukça yüksek olduğu görülmektedir (46). Nörogörüntüleme çalışmaları, kakao flavonoidlerinin etki edebilmesi için uzun süre (30 gün) tüketilmesi gerektiğini göstermektedir. Aynı şekilde antioksidan aktivitenin de ancak uzun süreli tüketimde etkin olabildiği bildirilmiştir (47).

Sorond ve arkadaşlarının (50) yaptığı çalışmada 450 mg kakao flavonunun serebrovasküler akım hızına etkisi değerlendirilmiş, birinci günde herhangi bir değişiklik gözlenmezken, 1 . ve 2 . haftalarda serebrovasküler akım hızında belirgin bir değişim olduğu görülmüştür.

Yüksek polifenol içeriğine sahip kakao tüketiminin insan davranış, bilişsel ve beyin işlevleri üzerine olası etkisinin mevcut olduğu, ancak çalışmalarda standart psikometrik test ve nöral görüntüleme protokollerinin uygulanması, uygun flavanol doz ve verilme süresinin saptanmasına gereksinim olduğu belirtilmiştir (49).

\section{SONUÇ VE ÖNERILER}

Sonuç olarak klinisyenlerin "sağlık için çikolata" ifadesini kullanabilmeleri için, büyük çaplı gözlemsel ve girişimsel önyargısız çalışmalara gereksinim olduğu belirtilmelidir. Bunun yanı sıra, çalışmalarda kullanılan ürünlerin çoğu, piyasada var olanlara göre daha yüksek polifenol içeriğine sahiptir. Zengin polifenol içeriği bitter tadı daha baskın hale getirebildiğinden, üreticilerin polifenol içeriğini zengin tutarken tadı da tüketilebilir düzeyde tutacak yöntemler geliştirmeleri gerektiğine dikkat çekilmelidir.

Çıkar çatışması - Conflict of interest: Yazarlar çıkar çatışması olmadığını beyan ederler. - The authors declare that they have no conflict of interest. 


\section{KAYNAKLAR}

1. Katz DL, Doughty $\mathrm{K}$, Ali A. Cocoa and chocolate in human health and disease. Antiox Redox Signal 2011;15(10):2279-2811.

2. Dilinger TL, Barriga P, Escarcega S, Jimenez M, Lowe DS, Grivetti LE. Food of the gods:cure for humanity? A cultural history of the medicinal and ritual use of chocolate. J Nutr 2000;130(8):2057-2072.

3. Ellam S, Williamson G. Cocoa and human health. Annu Rev Nutr 2013;33:105-128.

4. Bruinsma K, Taren DL. Chocolate: food or drug? J Am Diet Assoc 1999;99(10):1249-1256.

5. Beg Shavez M, Ahmad S, Jan K,Bashir K. Status, supply chain and processing of cocoa-A review. Trends Food Sci Technol 2017;66:108-116.

6. Ried K, Sullivan TR, Fakler P, Frank OR, Stocks NP. Effect of cocoa on blood pressure (review). Cochrane Database Syst Rev 2017;25(4).

7. Fermandez-Murga L, Tarin JJ, Gerafe-Parez, Cano A. The impact of chocolate on cardiovascular health. Maturitas 2011;69:312-321.

8. Beckett S.T. The Science of chocolate. 2nd edition, RSC Publishing. 2008.

9. Lima LJ, Almedia $\mathrm{MH}$, RoB Nout MJ, Zwietering $\mathrm{MH}$. Theobroma cocoa "the food of the gods": quality determinants of commercial cocoa beans, particular reference to the impact of fermentation. Crit Rev Food Sci Nutr 2011;51(8):731-761.

10. Rimbach G, Melchin M, Moehring J, Wagner AE. Polyphenols from cocoa and vascular health-a critical review. Int J Mol Sci 2009;10:4290-4309.

11. Turnbull CJ, Daymond AJ, Lake H, Main BE, Radha $\mathrm{K}$, Cryer NC, et al. The role of the international cocoa germplasm database and the international cocoa quarantine centre in information management and distribution of cocoa genetic resources. 16th International Cocoa Research Conference, November 2009, Bali.http://centaur.reading.ac.uk/28427/.

12. Övet B. Türkiye piyasasında bulunan çikolataların antioksidan kapasiteleri ve fenolik madde içerikleri yönünden araştırılması. 2005, Orta Doğu Teknik Üniversitesi, Gıda Mühendisliği Bölümü, Yüksek Lisans Tezi.

13. Tokede OA, Gaziano JM, Djousse L. Effects of cocoa products/dark chocolate on serum lipids: a metaanalysis. Eur J Clin Nutr 2011;65:879-886.

14. Buijsse B, Weikert C, Drogan D, Bergmann M, Boeing H. Chocolate consumption in relation to blood pressure and risk of cardiovascular disease in German adults. Eur Heart J 2010;31(13):1616-1623.
15. Mostofsky E, Levitan EB, Wolk A, Mittleman MA. Chocolate intake and incidence of heart failure a population-based prospective study of middle-aged and elderly women. Circ Heart Fail 2010;3:612-616.

16. Buitrago-Lopez A, Sanderson J, Johnson L, Warnakula S, Wood A, Di Angelantonio E, et al. Chocolate consumption and cardiometabolic disorders: systematic review and meta-analysis. BMJ 2011;343:1-8.

17. Pucciarelli DL. Cocoa and heart health: A historical review of the science. Nutrients 2013;(5):3854-3870.

18. Ingrid P, Karin P, Staffan H, Rolf GG A. Effects of cocoa extract and dark chocolate on angiotensin-converting enzyme and nitric oxide in human endothelial cells and healthy volunteers-a nutrigenomics perspective. J Cardiovasc Pharmacol 2011;57(1):44-50.

19. Hooper L, Kroon PA, Rimm EB, Cohn JS, Harvey I, A Le Cornu K, et al. Flavonoids, flavonoid-rich foods, and cardiovascular risk: a meta-analysis of randomized controlled trials. Am J Clin Nutr 2008;88(1):38-50.

20. Murphy KJ, Chronopoulos AK, Singh I, Francis MA, Moriarty H, Pike MJ, et al. Dietary flavanols and procyanidin oligomers from cocoa (Theobroma cacao) inhibit platelet function. Am J Clin Nutr 2003;77:14661473.

21. Wang JF, Schramm DD, Holt RR, Ensunsa JL, Fraga CG, Schmitz $\mathrm{HH}$, et al. A dose-response effect from chocolate consumption on plasma epicatechin and oxidative damage. J Nutr 2000;130:2115-2119.

22. Lettieri-Barbato D, Villano D, Beheydt B, Guadagni F, Trogh I, Serafini M. Effect of ingestion of dark chocolates with similar lipid composition and different cocoa content on antioxidant and lipid status in healthy humans. Food Chemistry 2012;132(3):1305-1310.

23. West SG, McIntyre MD, Piotrowski MJ, Poupin N, Miller DL, Preston A, et al. Effects of dark chocolate and cocoa consumption on endothelial function and arterial stiffness in overweight adults. Br J Nutr 2014;111:653661.

24. Engler MB, Engler MM, Chen CY, Malloy MJ, Browne A, Chiu EY, et al. Flavonoid-rich dark chocolate improves endothelial function and increases plasma epicatechin concentrations in healthy adults. J Am Coll Nutr 2004;23(3):197-204.

25. Jia L, Liu X, Bai YY, Li SH, Sun K, He C, et al. Short-term effect of cocoa product consumption on lipid profile: a meta-analysis of randomized controlled trials. Am J Clin Nutr 2010;92:218-225.

26. Shrime MG, Bauer SR, McDonald AC, Chowdhury NH, Coltart EM, Ding EL. Flavonoid-rich cocoa consumption affects multiple cardiovascular risk factors in a meta- 
analysis of short-term studies. J Nutr 2011;141:19821988.

27. Hooper L, Kay C, Abdelhamid A, Kroon PA, Cohn JS, Rimm EB, et al. Effects of chocolate, cocoa, and flavan3-ols on cardiovascular health: a systematic review and meta-analysis of randomized trials. Am J Clin Nutr 2012;95:740-751.

28. Hamed MS, Gambert S, Bliden K, Bailon O, Anand S, Antonino MJ, et al. Dark chocolate effect on platelet activity, c-reactive protein and lipid profile: a pilot study. South Med J 2008;101(12):1203-1208.

29. Stote KS, Clevidence BA, Novotny JA, Henderson T, Radecki SV, Baer DJ. Effect of cocoa and green tea on biomarkers of glucose regulation, oxidative stress, inflammation and hemostasis in obese adults at risk for insulin resistance. Eur J Clin Nutr 2012;66:1153-1159.

30. Crichton G, Elias MF, Dearbom P, Robbins M. Habitual chocolate intake and type 2 diabetes mellitus in the Maine-Syracuse Longitudinal Study: (1975-2010): Prospective observations. Appetite 2017;108:263-269.

31. Hooper L, Kay C, Abdelhamid A, Kroon PA, Cohn JS, Rimm EB, et al. Effects of chocolate, cocoa, and flavan3-ols on cardiovascular health: a systematic review and meta-analysis of randomized trials. Am J Clin Nutr 2012;95:740-751.

32. Houston DK, Stevens J, Cai J, Haines PS. Dairy, fruit, and vegetable intakes and functional limitations and disability in a biracial cohort: the Atherosclerosis Risk in Communities Study. Am J Clin Nutr 2005;81:515-522.

33. Oba S, Nagata C, Nakamura K, Fujii K, Kawachi T, Takatsuka N, et al. Consumption of coffee, green tea, oolong tea, black tea, chocolate snacks and the caffeine content in relation to risk of diabetes in Japanese men and women. Br J Nutr 2010;103:453-459.

34. Hollenberg NK. Vascular action of cocoa flavanols in humans: the roots of the story. J Cardiovasc Pharmacol 2006;47(2):99-102.

35. Grassi D, Necozione S, Lippi C, Croce G, Valeri L, Pasqualetti $\mathrm{P}$, et al. Cocoa reduces blood pressure and insulin resistance and improves endotheliumdependent vasodilation in hypertensives. Hypertension 2005;46:398-405.

36. Corti R, Flammer AJ, Hollenberg NK, Lüscher TF. Cocoa and cardiovascular health. Circulation 2009;119:14331441.

37. Ellinger S, Reusch A, Stehle P, Helfrich HP. Epicatechin ingested via cocoa products reduces blood pressure in humans: a nonlinear regression model with a Bayesian approach. Am J Clin Nutr 2012; 95(6):1365-1377.

38. Murphy KJ, Chronopoulos AK, Singh I, Francis MA, Moriarty $\mathrm{H}$, Pike MJ, et al. Dietary flavanols and procyanidin oligomers from cocoa (theobroma cacao) inhibit platelet function. Am J Clin Nutr 2003;77:1466-1473.

39. Crews WD Jr, Harrison DW, Wright JW. A doubleblind, placebo-controlled, randomized trial of the effects of dark chocolate and cocoa on variables associated with neuropsychological functioning and cardiovascular health: clinical findings from a sample of healthy, cognitively intact older adults. Am J Clin Nutr 2008;87:872-880.

40. Njike VY, Faridi Z, Shuval K, Dutta S, Kay CD, West G, et al. Effects of sugar-sweetened and sugar-free cocoa on endothelial function in overweight adults. Int J Cardiol 2011;149(1):83-88.

41. Di Renzo L, Rizzo M, Sarlo F, Colica C, Iacopino L, Domino E, et al. Effects of dark chocolate in a population of normal weight obese women: a pilot study. Eur Rev Med Pharmacol Sci 2013;17:2257-2266.

42. Maurage P, Heeren A, Pesenti M. Does chocolate consumption really boost nobel award chances? The peril of over-interpreting correlations in health studies. J Nutr 2013;143:931-933.

43. Gu Y, Hurst WJ, Stuart DA, Lambert JD. Inhibition of key digestive enzymes by cocoa extracts and procyanidins. J Agric Food Chem 2011;59(10):5305-5311.

44. Almoosawi S, Tsang C, Ostertag LM, Fyfe L, Al-Dujaili EA. Differential effect of polyphenol-rich dark chocolate on biomarkers of glucose metabolism and cardiovascular risk factors in healthy, overweight and obese subjects: a randomized clinical trial. Food Funct 2012;3(10):10351043.

45. Afoakwa EO. Cocoa and chocolate consumption - Are there aphrodisiac and other benefits for human health? S Afr J Clin Nutr 2008;21(3):107-113.

46. Franco R, Oñatibia-Astibia A, Martínez-Pinilla E. Health benefits of methylxanthines in cacao and chocolate. Nutrients 2013;5:4159-4173.

47. Martin FP, Rezzi S, Peré-Trepat E, Kamlage B, Collino S, Leibold E, Kastler J, et al. Metabolic effects of dark chocolate consumption on energy, gut microbiota, and stress-related metabolism in free-living subjects. J Proteome Res 2009;8(12):5568-5579.

48. Meier BP, Noll SW, Molokwu OJ. The sweet life: The effect of mindful chocolate consumption on mood. Appetite 2017;1:108:21-27.

49. Sokolov AN, Pavlova MA, Klosterhalfen S, Enck P. Chocolate and the brain: Neurobiological impact of cocoa flavanols on cognition and behavior. Neurosci Biobehav Rev 2013;37(10):2445-2453.

50. Sorond FA, Lipsitz LA, Hollenberg NK, Fisher ND. Cerebral blood flow response to flavanol-rich cocoa in healthy elderly humans. Neuropsychiatr Dis Treat 2008;4(2):433-440. 